\title{
The Peahen's Duckling
}

\author{
Judoe L. T. McKim
}

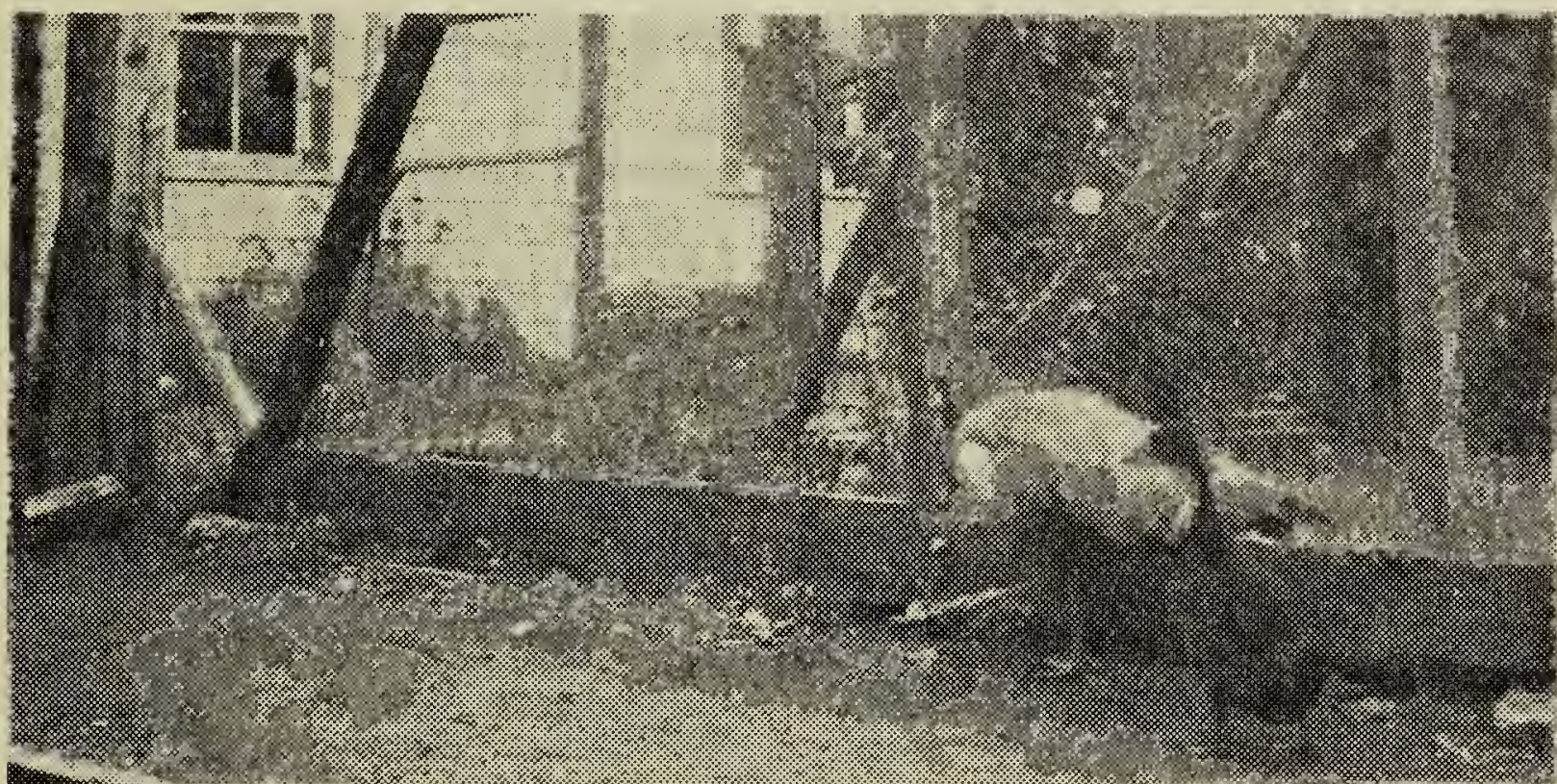

The above snap shot was taken at Inglewood Bird Sanctuary, Calgary, in August this year. A peahen lost her eggs and usurped the nest of a duck and raised one young one. The ciuckling is a cross between a tame black duck and a mallard.

Many thousands of wild geese and ducks spend the winter in the sanctuary and are fed by various companies. A spring keeps a considerable body of water open all winter.

\section{Our Whistling Swan C. Stuart Francis, Torch River}

AST WEDNESDAY, November 7, $\triangle$ I had the very great thrill of obtaining a Whistling Swan to add to my flock of Canada Geese, Snow Geese, etc., through rather unusual circumstances.

A farmer north of the village of Garrick was driving along the main road, when he suddenly saw a Swan sitting right in the middle of the road. He, of course, expected it to take wing as he drew closer to it, but at the last moment was forced to step on the brakes to avoid running over it. It did not move so he picked it up and put it into his truck cab anc? took it home, fearing that foxes or coyotes would soon kill it, or that it would perish in the subzero temperatures. After keeping it a week or so, he decided he had no proper place for it, or no other waterfowl to keep it company. He offered it to us and of course we were only too pleased to accept.

The burd was in rather bad shape, very thin and weak and blind in one cye. We put it in with our Wild Geese, and the discovery by the
Swan that it was with former acquaintances seemed to brighten him up. We are giving him lots of w a t e r, gravel, oat-sheaves, a n $d$ mixed wheat, barley and oat chop. He seems to be getting stronger every day and is so tame already that he goes in and out of the Wild Goose rouse at will.

If this whistling Swan lives and thrives we will, in our family, always be grateful to the kind and thoughtful farmer who gave him to us, as too few persons would have taken the trouble to try to save the life of such a magnificent species of our natire wildlife.

\section{Richardson Owl}

Madoline Runyan, Punnichy

GOR three months last winter our hay loft was occupied by a tiny owl. We often saw him with a mouse, so he was a welcome visitor. One day, at noon, as he sat blinking in the sun, I approached to within three feet and took a very good snap with a portrait attachment. After looking at the owls in the Provincial museum we were able to identify this little one as a Richardson Owl. 